\section{SEEDS}

Surrey Energy Economics

Discussion paper Series
SuRrey

ENERGY

ECONOMICS

Centre

\title{
An Analysis of UK Energy Demand Using Multivariate Cointegration
}

\author{
Lester C Hunt and Robert Witt
}

December 1995

SEEDS 86

ISBN 1-85237-180-3

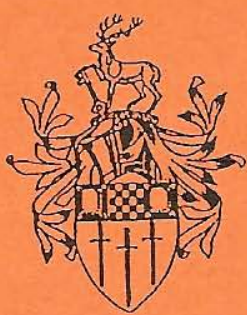

Department of Economics University of Surrey 
SEEC consists of members of the Department of Economics who work on energy and environmental economics. SEEC's aims include the promotion of research and teaching in the broad area of energy economics and policy. SEEC was founded in 1983. Its creation was intended to consolidate the research on energy economics which developed at the University of Surrey after the appointment of Colin Robinson to the Chair of Economics in 1968. Colin and the colleagues he attracted to the University built up Surrey's reputation, initially with pioneering work on North Sea oil and gas, and subsequently in all the other major areas of energy economics.

- Recent research covers the following areas: Electricity, gas and coal privatisation in the UK; privatisation in the Middle East; the structure of UK energy demand; North Sea oil and gas economics and policy: international oil markets; electricity economics; the transport of energy; environmental policy in the UK; energy and environmental policy in the Third World; global environmental issues.

- SEEC research output includes SEEDS - Surrey Energy Economics Discussion paper Series (recent titles may be found on the backcover), as well as a range of other academic papers, books and monographs including SEEC OCCASIONAL PAPERS.

- Each year SEEC organises a range of energy conferences and workshops on energy themes. Specialist workshops include the meetings of the the joint SEEC/BIEE Energy Modelling Group, convened by David Hawdon and Paul Appleby (BP).

- Members of SEEC provide major inputs into the postgraduate energy courses run by the Economics Department - in particular, the M.Sc. courses on Energy Economics and Energy Policy, and the Diploma in the Economics of Energy and Development for Graduates.

Enquiries:

Director of SEEC

and Editor of SEEDS: David Hawdon Secretary: Isobel Hildyard

E-mail:D.Hawdon@surrey.ac.uk

E-mail: I.Hildyard@surrey.ac.uk

SEEC, Economics Dept, University of Surrey, Guildford GU2 5XH, UK.

Telephone: +44-(0)1483-259379

Fax: + 44-(0)1483-303775 


\section{Surrey Energy Economics Discussion paper Series}

SEEDS No. 86

\section{An Analysis of UK Energy Demand \\ Using Multivariate Cointegration}

Lester C Hunt*, University of Portsmouth

and

Robert Witt*, University of Surrey

* The authors would like to thank Terry Barker and participants at the British Institute Energy Economics conference in Warwick (December, 1995) for a number of contructive comments. However, the usual disclaimer applies.

This paper may not be reproduced without permission.

ISBN: $1-85237-180-3$

December 1995

British Library Cataloguing-in-Publication Data.

A catalogue record for this book is available from the British Library. 


\title{
An Analysis of UK Energy Demand Using Multivariate Cointegration
}

\begin{abstract}
In this paper we estimate an aggregate energy demand equation by a maximum likelihood procedure proposed by Johansen (1988) for the UK using annual data from 1967 to 1994 . The influence of the price of energy, income and temperature on energy consumption is examined. A unique long-run equilibrium relationship between energy demand, income and price is found to exist for the period, with temperature affecting demand only in the short-run. The resultant estimated elasticities are robust to different specifications and corroborates the findings of Hunt and Manning (1989) although a weaker long-run effect of income on energy demand was observed.
\end{abstract}

JEL Classification: Q41 


\section{INTRODUCTION}

The estimation of energy price and income elasticities has commanded considerable interest in the recent past. There are a number of reasons why the importance attached to estimating the parameters of energy demand functions should not be understated. Firstly, it provides information necessary for the calculation of future energy demand. Secondly, knowledge of the strength of energy demand responses assists in the evaluation and design of macroeconomic policy given the relative importance of energy sectors in many national economies. Finally, the need for accurate estimates is more prevalent than ever given the environmental agenda will become more closely aligned to the energy policy agenda.

In this paper we present maximum likelihood estimates of the relationship(s) between energy consumption, price and income. The response by economic agents within a country to changes in energy prices and income varies significantly depending on, inter alia, the sector of the economy and different fuel uses. However, to assess the overall impact of changes in certain key variables or 
changes in policy, aggregate energy demand elasticities are a useful aid in analysing the impact on energy consumption and hence the environment (see e.g. Pearson and Smith 1991).

Hunt and Manning (1989) estimated price- and income-elasticities of aggregate energy demand for the UK over the period 1967-1986 using the Engle and Granger (1987) two-step cointegration procedure. They found a long-run price elasticity of about -0.3 and a long-run income elasticity of about 0.5 . In this paper we estimate an aggregate energy demand equation by a maximum likelihood procedure proposed by Johansen (1988) for the UK using annual data from 1967 to 1994 . From this method we can test for the number of co-integrating relationships. This, in turn, enables us to test hypotheses concerning the individual elements of the cointegrating vectors (see e.g. Muscatelli and Hurn, 1992).

The model and data is described in the next section. Section III discusses our results while Section IV offers conclusions. 


\section{DATA AND UNDERLYING MODEL}

The underlying aggregate energy demand equation to be explored is given by:

$$
\ln \mathrm{E}_{\mathrm{t}} \quad=\mathrm{f}\left(\ln \mathrm{P}_{\mathrm{t}}, \ln \mathrm{Y}_{\mathrm{t}}, \mathrm{JT}_{\mathrm{t}}\right)
$$

where: $\mathrm{E}_{\mathrm{t}} \quad=$ aggregate energy consumption;

$$
\begin{aligned}
& \mathrm{P}_{\mathrm{t}}=\text { real price of energy; } \\
& \mathrm{Y}_{\mathrm{t}}=\text { real income; and } \\
& \mathrm{JT}_{\mathrm{t}}=\text { January temperature. }
\end{aligned}
$$

$\mathrm{E}$ is aggregate energy consumption by final user (energy supplied basis) obtained from the 1995 Digest of United Kingdom Energy Statistics (DUKES). The nominal price of energy is derived by dividing the estimated expenditure on energy by final users (as given in various issues of $D U K E S$ ) by energy consumption, $\mathrm{E} . \mathrm{P}$ is calculated by deflating the nominal energy price by the GDP deflator given in the Economic Trends Annual Supplement, 1995 and Economic Trends August 1995. Y is GDP at 1990 factor cost also taken from the two Economic Trends publications. JT is the GB mean air temperature in degrees celsius for January of each year 
taken from the 1995 DUKES. This gives an annual data set from 1967, the first year for which estimated expenditure on energy is available, up to 1994. (Note that E, Y and P are entered in natural logarithms whereas JT is not.)

\section{EMPIRICAL RESULTS}

In order to test for the presence of unit roots, and hence to establish the order of integration of the variables in the data set, we use the Dickey-Fuller (DF) and the Augmented Dickey Fuller (ADF) test statistics (Fuller, 1976). The results are given in Table $1^{1}$. In what follows, we shall proceed on the assumption that $\operatorname{lnE}$ and $\ln \mathrm{P}$ are difference stationary, whilst $\ln Y$ may be more adequately described as trend rather than difference stationary (Banerjee et al., 1993). However, Table 1 gives evidence that JT is stationary over the sample period. Figure 1 plots the time series of the data over the period 1967 to 1994 . Inspection of the log levels and the temperature series appears to support the test statistics reported in Table 1.

1 All estimation was conducted using PC-Give and/or PC-Fiml 8.0. 
TABLE 1: Unit Root Tests

\begin{tabular}{||c|c|c|c||}
\hline & $I(1) v I(0)$ & & $I(2) v I(1)$ \\
\hline Variable & $D F$ & $A D F$ & $D F$ \\
\hline $\ln E$ & -2.57 & & -4.78 \\
\hline $\ln P$ & -1.63 & & -4.28 \\
\hline $\operatorname{InY}$ & & $-3.02(1)$ & -3.68 \\
\hline JT & -3.51 & & - \\
\hline
\end{tabular}

Notes:

1 Table 1 gives no evidence that $\ln \mathrm{E}, \ln \mathrm{P}$ and $\ln \mathrm{Y}$ are $\mathrm{I}(0)$ over our sample period. However, we can assume that temperature is a $\mathrm{I}(0)$ variable. Our estimates are based on a regression including a constant. For $\ln Y$ regression we include a constant and a time trend.

2 Figures in parentheses denote the number of lagged differences in auxiliary regression.

3 Approximate $5 \%$ critical values when excluding and including a trend are -2.98 and -3.59 respectively. 


\section{FIGURE 1}
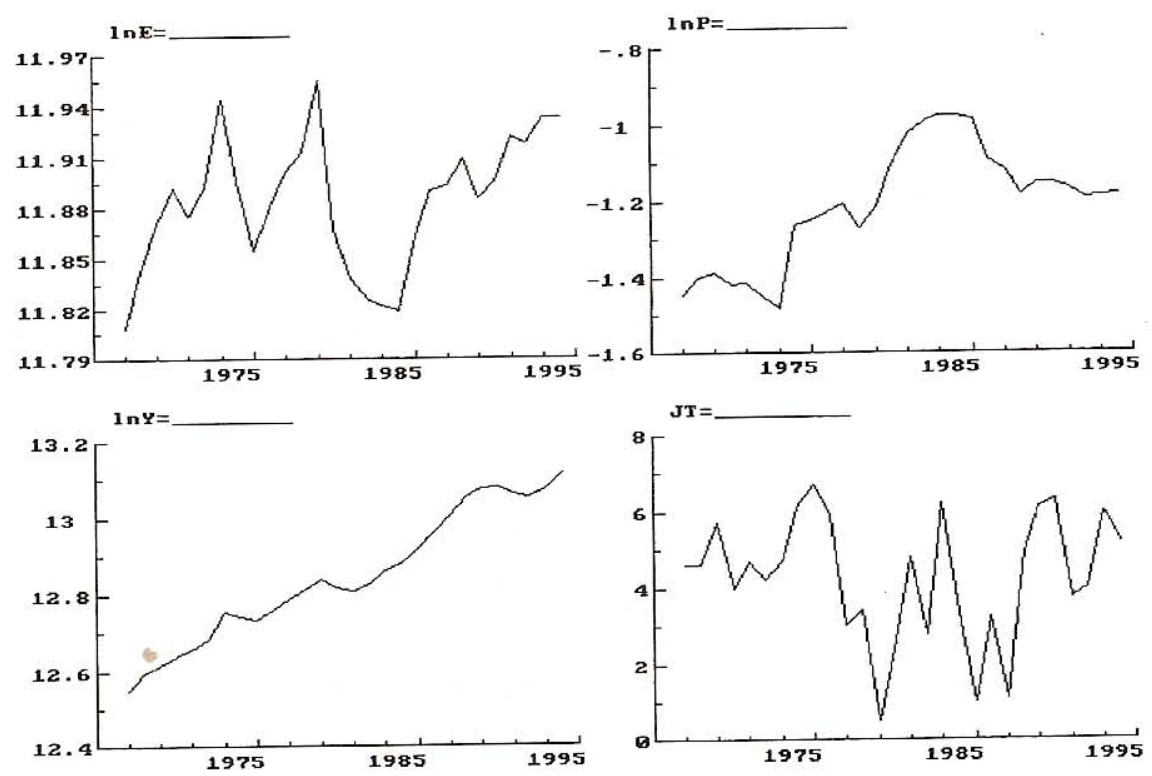

The Johansen (1988) approach estimates cointegrating relationships between non-stationary variables using a maximum likelihood procedure. This technique tests for the number of distinct cointegrating vectors in a multivariate setting and estimates the parameters of these cointegrating relationships. Consider the threedimensional vector autoregressive model 
$\mathbf{X}_{t}=\mathbf{A}_{1} \mathbf{X}_{t-1}+\cdots+\mathbf{A}_{k} \mathbf{X}_{t-k}+\varepsilon_{t}$,

$\mathrm{t}=1, \ldots \ldots \ldots, \mathrm{T}$

where $\mathbf{X}_{t}=[\ln (E), \ln (P), \ln (Y)]_{t}$ as defined above, $\mathbf{X}_{t}$ are fixed and $\varepsilon_{\mathbf{t}} \sim \operatorname{IN}(0, \Sigma)$. We can write model (1) in error correction form:

$\Delta \mathbf{X}_{\mathrm{t}}=\Gamma_{1} \Delta \mathbf{X}_{\mathrm{t}-1}+\cdots+\Gamma_{\mathrm{k}-1} \Delta \mathbf{X}_{\mathrm{t}-\mathrm{k}+1}+\Pi \mathbf{X}_{\mathrm{t}-\mathrm{k}}+\Psi \mathbf{D}_{\mathrm{t}}+\varepsilon_{\mathrm{t}}$,

$\mathrm{t}=1, \ldots \ldots, \mathrm{T}$,

where the $\mathbf{D}_{t}$ vector is assumed to be made up of $\mathrm{I}(0)$ variables, such as temperature. The data $\left\{\mathbf{X}_{\mathrm{t}}\right\}$ are integrated of order one, I(1), then $\Delta\left\{\mathbf{X}_{\mathbf{t}}\right\}$ is $\mathrm{I}(0)$ and the reduced form model (2) is balanced only if $\Pi \mathbf{X}_{t-k}$ is $I(0)$. Thus, matrix $\Pi$ has to be of reduced rank:

$$
\Pi=\alpha \beta^{\prime},
$$

where $\beta$ may be interpreted as the $\mathrm{p} \times \mathrm{r}$ matrix of cointegrating vectors and $\alpha$ is the $\mathrm{p} \times \mathrm{r}$ matrix of loading weights.

Given the outcome of the unit root tests $\ln \mathrm{E}, \ln \mathrm{P}$ and $\ln \mathrm{Y}$ were entered as endogenous variables and JT as an exogenous variable in the unrestricted VAR equation (1). In other words we allow for $\ln P$ and $\ln Y$ to have a role in the long-run whereas JT only exerts a short-run influence ${ }^{2}$. The lag length of the $I(1)$ variables were

2 The constant is entered in a similar way to JT. 
initially set to $\mathrm{k}=4$. The final lag length was then selected by sequentially testing from the lag length of four on all the I(1) variables downwards using the likelihood ratio principle and using the F-tests for the hypothesis that the ith period lag in the equations is zero (see below). This resulted in the final unrestricted VAR with $\mathrm{k}=1$. The diagnostic tests from the system with $\mathrm{k}$ set to 1 are given in Table 2.

All of the diagnostic tests are passed other than the heteroscedasticity test for the $\ln \mathrm{P}$ equation. However, when testing the vector as a whole, the heteroscedasticty test along with all the others is passed. In addition the importance of JT (and the constant) is seen by the final vector test for the unrestricted variables which convincingly rejects the null that they are not significant. 


\section{TABLE 2:}

Goodness of Fit and Model Evaluation, 1968-1994, lag length, $\mathbf{k}=\mathbf{1}$

\begin{tabular}{||l|l|l|l|l||}
\hline \multicolumn{1}{|c|}{ Statistic } & \multicolumn{1}{c|}{$\ln \mathbb{E}$} & \multicolumn{1}{c|}{$\ln \mathrm{P}$} & \multicolumn{1}{c|}{$\ln \mathrm{Y}$} & \multicolumn{1}{c||}{ VAR } \\
\hline $\mathrm{F}_{\mathrm{k}=1}(3,20)$ & $3.37^{* *}$ & $17.16^{* * *}$ & $158.75^{* * *}$ & \\
\hline$\sigma$ & $2.25 \%$ & $6.00 \%$ & $2.21 \%$ & \\
\hline $\mathrm{F}_{\text {ar }}(2,20)$ & 0.40 & 0.02 & 2.14 & \\
\hline $\mathrm{F}_{\text {arch }}(1,20)$ & 0.03 & 0.01 & 0.01 & \\
\hline $\mathrm{F}_{\text {het }}(6,15)$ & 1.16 & $3.91^{* *}$ & 0.75 & \\
\hline$\chi_{\text {nd }}(2)$ & 0.48 & 3.06 & 2.18 & \\
\hline$F_{\text {ar }}(18,40)$ & & & & 1.33 \\
\hline$F_{\text {het }}(36,46)$ & & & & 1.32 \\
\hline$\chi_{\text {nd }}(6)$ & & & & 8.22 \\
\hline$F_{\text {ur }}(9,48)$ & & & & $67.71^{* * *}$ \\
\hline
\end{tabular}

\section{Notes:}

The tests involve F-tests for the hypothesis that the i-period lag $\left(\mathrm{F}_{\mathrm{k}=\mathrm{i}}\right)$ is zero; that there is no serial correlation ( $\mathrm{F}_{\mathrm{ar}}$ against 2nd order autoregression); that there is no autoregressive conditional heteroscedasticity ( $F_{\text {arch }}$ against 1 st order); that there is no heteroscedasticity $\left(\mathrm{F}_{\text {het }}\right)$; and the normality test used in PC-Give and PC-Fiml $\left(\chi_{\text {nd }}\right)$. Similar vector tests are also given with the extra statistic $\left(\mathrm{F}_{\mathrm{ur}}\right)$ representing the test against the significance of the unrestricted $\mathrm{I}(0)$ regressors.

Given the system with $\mathrm{k}=1$, Table 3 report the tests for the number of cointegrating vectors. This reports both the $\lambda_{\max }$ and the Trace statistics. Table 3 also gives these statistics adjusted for the 
number of degrees of freedom (as suggested by Reimers, 1992) given the small number of observations in the model. In addition the $10 \%$ critical values are presented from Osterwald-Lenum $(1992)^{3}$

\section{TABLE 3: Testing the Rank of $\Pi$}

\begin{tabular}{|c|c|c|c|c|c|c|c|c|c|}
\hline $\begin{array}{l}\text { Trac } \\
e \\
\mathbf{H}_{0}\end{array}$ & $\mathbf{H}_{1}$ & $\begin{array}{l}\text { Calc. } \\
\text { Stat. } \\
\end{array}$ & $\begin{array}{l}\text { Adj. } \\
\text { Stat. }\end{array}$ & $90 \%$ & $\begin{array}{l}\lambda_{\max } \\
\mathbf{H}_{0}\end{array}$ & $\mathbf{H}_{1}$ & $\begin{array}{l}\text { Calc. } \\
\text { Stat. } \\
\end{array}$ & $\begin{array}{l}\text { Adj. } \\
\text { Stat. }\end{array}$ & $90 \%$ \\
\hline$r=0$ & $r \geq 1$ & $29.37^{*}$ & 26.11 & 26.8 & $r=0$ & $r=1$ & $23.80^{* *}$ & $21.15^{* *}$ & 18.6 \\
\hline$r \leq 1$ & $r \geq 2$ & 5.57 & 4.95 & 13.3 & $r \leq 1$ & $r=2$ & 4.29 & 3.82 & 12.1 \\
\hline$r \leq 2$ & $r \geq 3$ & 1.28 & 1.14 & 2.7 & $r \leq 2$ & $r=3$ & 1.28 & 1.14 & 2.7 \\
\hline
\end{tabular}

Note: ${ }^{* *}$ and $*$ denote statistical significance at the $5 \%$ and $10 \%$ level respectively.

Table 3 shows that the null hypothesis of one cointegrating vector cannot be rejected at the $10 \%$ level using the original Trace statistic. This is not the case with the adjusted version. For the $\lambda_{\max }$ statistic however, the null hypothesis of one cointegrating vector cannot be rejected at the $5 \%$ level using the original and the adjusted version. This slight contradiction in the tests for cointegration is not uncommon. Consequently it is assumed in

3 The inclusion of $\mathrm{I}(0)$ variables affects the underlying distribution of these test statistics. Therefore, the critical values are only indicative in this case. 
subsequent analysis that one stationary relationship exists in this data set $^{4}$. Thus we can now turn to the individual estimates as given in Table 4.

TABLE 4: $\alpha$ and $\beta$ Vectors

\begin{tabular}{|c|c|c|}
\hline Variable & $\beta_{1}^{\prime}$ & $\alpha_{1}$ \\
\hline $\ln \mathbf{E}$ & $-1.000(4.26)$ & $-0.871 \quad(4.11)$ \\
\hline $\ln \mathbf{P}$ & $-0.271(4.13)$ & $\begin{array}{ll}0.467 & (0.96) \\
\end{array}$ \\
\hline $\ln Y$ & 0.215 & $-0.349(2.07)$ \\
\hline
\end{tabular}

Note: $t$-statistics are given in parentheses.

The $t$-statistics for the individual parameters (calculated by the method suggested by Juselius and Hargreaves 1992) shows that the parameters in the $\beta$ vector are all individually significantly different from zero. Turning to the $\alpha$ vector it is clear that $\alpha_{1,1}$, the loading associated with the $\operatorname{lnE}$ equation is significantly different from zero. Similarly, it is equally clear that $\alpha_{1,2}$, the loading for the $\ln \mathrm{P}$ equation is not significantly different from zero. Thus $\ln \mathrm{P}$ may be regarded as weakly exogenous from the model. $\alpha_{1,3}$, however, is

\footnotetext{
4 It is worth noting that the omission of the temperature variable would lead to the conclusion that there are no cointegrating relationships and hence no long-run relationship between $1 \mathrm{nE}, \ln \mathrm{P}$ and $\operatorname{lnY}$. However, there is no discernible difference in the estimated elasticities over the 1968-1994 period if temperature is included or not.
} 
borderline. That is, it is not clear whether $\ln \mathrm{Y}$ may be regarded as weakly exogenous to this system or not. Therefore, the joint restriction that $\ln \mathrm{P}$ and $\ln \mathrm{Y}$ are weakly exogenous (i.e. $\alpha_{1,2}=0$ and $\alpha_{1,3}=0$ ) was imposed. This yielded a likelihood ratio statistic $\chi_{(2)}=$ 4.283 suggesting that the joint null of both being weakly exogenous cannot be rejected. It is assumed therefore that $\ln \mathrm{Y}$ and $\ln \mathrm{P}$ are weakly exogenous to the system. Imposing the joint restriction gives the estimates presented in Table 5.

TABLE 5: $\beta$ and Restricted $\alpha$ Vectors

\begin{tabular}{|c|c|c|}
\hline Variable & $\beta_{i}$ & $\alpha_{1}$ \\
\hline $\ln E$ & $\begin{array}{r}-1.000 \\
(4.18)\end{array}$ & -0.655 \\
\hline $\ln \mathbb{P}$ & $\begin{array}{r}-0.286 \\
(4.14)\end{array}$ & - \\
\hline $\ln Y$ & $\begin{array}{l}0.228 \\
(3.59)\end{array}$ & - \\
\hline
\end{tabular}

Notes. See table 4.

The significant parameter estimates in the $\beta$ vector for $\ln \mathrm{P}$ and $\ln Y$, representing the long-run elasticity estimates, show a similarity with the coefficient estimates in the long-run equation reported by Hunt and Manning (1989). However, the estimates reported here 
do imply a much lower elasticity with respect to income compared with those found by Hunt and Manning. The estimated elasticity of 0.23 suggests that a ceteris paribus rise in GDP of $1 \%$ raises energy consumption by about $0.2 \%$. It is possible that as consumers become saturated with energy efficient capital and appliances, the effect of income on energy demand will become negligible in the long run. We experimented with different estimation periods and found that when additional years were added to the period 1967 1986 the income elasticity began to fall before settling at the lower level as presented in Table 5. This was not true for the long-run price elasticity however which was fairly robust to different estimation periods.

Having obtained the long-run cointegrating relationship using the Johansen procedure it is possible to estimate the short-run model directly with the error-correction term (ECM) explicitly included. This ensures that the restricted model is consistent with the underlying data and provides estimates of the short-run responses to changes in the price of energy, income and temperature. Since $\ln P$ and $\ln Y$ were found to be weakly exogenous in the system only one 
equation need be estimated for $\Delta \ln E$ conditioned on $\Delta \ln P, \Delta \ln Y$ and JT using OLS. Therefore a dynamic equation for the differences of the I(1) variables to ensure stationarity, along with JT and the EC $\left(\boldsymbol{\beta}^{\prime} \mathbf{X}_{\mathrm{t}-1}\right)$ term is given in Table 6 . We experimented with various lag lengths, employing the general to specific modelling strategy, but our preferred model was one that only included the contemporaneous terms for the first differenced variables.

TABLE 6: OLS Energy Estimates, ECM

(Sample Period 1968-1994)

\begin{tabular}{|c|c|}
\hline Variable & $\Delta \ln E_{t}$ \\
\hline Constant & $\begin{array}{l}5.648^{* * * *} \\
(4.82)\end{array}$ \\
\hline$\Delta \ln \mathbf{P}_{t}$ & $\begin{array}{l}-0.151^{* *} \\
(2.45)\end{array}$ \\
\hline$\Delta \ln \mathbf{Y}_{t}$ & $\begin{array}{l}0.400^{* *} \\
(2.28)\end{array}$ \\
\hline $\mathrm{JT}_{\mathrm{t}}$ & $\begin{array}{l}-0.0062^{* * *} \\
(2.94)\end{array}$ \\
\hline $\mathbf{E C}_{t-1}$ & $\begin{array}{l}-0.653^{* * *} \\
(4.82)\end{array}$ \\
\hline $\mathbf{R}^{2}$ & 0.766 \\
\hline$\sigma$ & $1.64 \%$ \\
\hline$F_{\mathrm{ar}}(2,20)$ & 0.35 \\
\hline$F_{\text {arch }}(1,20)$ & 0.04 \\
\hline$\chi_{n d}(2)$ & 0.05 \\
\hline$F_{\text {reset }}(1,21)$ & $3.80^{*}$ \\
\hline $\mathbf{F}_{\text {het }}(\mathbf{8}, \mathbf{1 3})$ & 1.56 \\
\hline
\end{tabular}

Notes: $\Delta$ denotes the first difference operator. $t$-statistics are in parentheses. See notes to Table 2. 
The equation reported in Table 6 performs well passing all standard diagnostic tests with the exception of the RESET test at the $10 \%$ level. Moreover the estimated coefficient for the error correction term of -0.653 is highly significant, suggesting that about two-thirds of any disequilibrium is adjusted each year. This is very close to the EC coefficient in Hunt and Manning (1989) of -0.669 , suggesting that the speed of adjustment is robust to the different estimation periods and techniques. The short-run impact elasticities for price and income are -0.15 and 0.40 respectively. These compare with -0.1 and 0.6 for income in Hunt and Manning (1989).

Although the estimates of both the short- and long-run income elasticities are lower than in Hunt and Manning the relative size between the two is the same. That is, the short-run impact elasticity is greater than the long-term elasticity suggesting the inflexibility of firms' and households' energy-using capital and appliance stocks in the short-run. This suggests that an increase in income will bring about an immediate increase in the derived demand for energy in the short-term but this derived demand is reduced in the longer 
term as more energy efficient capital and appliances are installed.

However, the long-run price-elasticity is greater in absolute terms than the short-run elasticity so that a change in the real price of energy has a greater impact in the longer term. This reflects the fixed nature of the capital and appliance stocks in that a rise in the real price of energy produces a small reduction in the consumption in the short-term whereas in the long-term the price increase persuades agents to install more energy-efficient capital and appliance stocks.

Finally, unlike Hunt and Manning (1989) this model includes the temperature variable $\mathrm{JT}^{5}$. The impact (or short-run) effect of a ten degree celsius decrease in the average January temperature is to increase energy consumption by about $0.1 \%$.

\footnotetext{
5 As stated earlier, $\mathrm{JT}$ is needed to ensure that there is a cointegrating energy demand relationship. This applies equally to the period up to 1986 as well as 1994, suggesting that the Hunt and Manning (1989) model was misspecified. However, when re-estimating up to 1986 including the $\mathrm{JT}$ variable using the Johansen procedure, the estimated long-run price and income elasticities are very similar to those reported by Hunt and Manning.
} 


\section{CONCLUSIONS}

In this paper we have presented maximum likelihood estimates, based on annual aggregate time series data from 1967 to 1994, for the effects of price, income and temperature on energy consumption. A unique long-run equilibrium relationship between energy demand, price and income is found to exist for the period, with temperature affecting demand only in the short-run. This is in line with one's priors.

The Engle-Granger (1987) procedure used in previous aggregate energy studies for the UK (see, for example, Hunt and Manning, 1989, Hunt and Lynk, 1992) did not allow a test for the restrictions on the long-run solution of the model, whilst the Johansen procedure used in this paper does. The joint restriction that the logarithms of price and income are weakly exogenous could not be rejected by the data. Our study corroborates the findings of Hunt and Manning, although a weaker long-run effect of income on energy demand was observed.

An important finding in this paper was the extremely robust negative coefficient on the error correction term, a result which 
appears invariant to the estimator used. The magnitude of this effect of -0.653 is highly significant, suggesting that about two-thirds of any disequilibrium is adjusted each year. However, it must be stressed that the specification estimated is a relatively simple one. More complex factors omitted from the specification may have an important role in determining energy consumption. Nevertheless, taken together these results assign an important role to price, income and temperature in the determination of energy demand in the UK. 


\section{REFERENCES}

Banerjee, A., Dolado, J. Galbraith, J.W. and Hendry, D.F. (1993). Co-Integration, Error-Correction, and the Analysis of Nonstationary Data. Oxford: Oxford University Press.

Engle, R. F. and Granger, C. W. J. (1987). Cointegration and error correction: representation, estimation and testing, Econometrica, 55, pp. 251-276.

Fuller, W.A. (1976). Introduction to Statistical Time Series. New York. Wiley.

Hunt, L. C. and Lynk, E. L. (1992). Industrial energy demand in the UK: a cointegration approach, chapter 5 in Hawdon, D. (ed.) Energy Demand: Evidence and Expectations, Surrey University Press, Guildford.

Hunt, L. C. and Manning, D. N. (1989). Energy price- and incomeelasticities of demand: some estimates for the UK using the cointegration procedure, Scottish Journal of Political Economy, 36, pp. 183-193.

Johansen, S (1988). Statistical analysis of cointegtration vectors, Journal of Economic Dynamics and Control, 12, pp. 231-254.

Juselius, K. and Hargreaves C.P. (1992). Long-run relations in Australian monetary data, chapter 10 in Hargreaves, C.P. (ed.) Macroeconomic Modelling of the Long Run, Edward Elgar.

Muscatelli, V. A. and Hurn, S. (1992). Cointegration and dynamic time series models, Journal of Economic Surveys, 6, pp. 1-44.

Osterman-Lemun, M. (1992). A note with quantiles of the asymptotic distribution of the ML cointegration rank test statistics', Oxford Bulletin of Economics and Statistics, 54, pp. 461 - 472. 
Pearson, M. and Smith, S. (1991). The European Carbon Tax: An Assessment of the European Commission's Proposals, The Institute of Fiscal studies

Reimers, H-E. (1992). Comparison of tests for multivariate cointegration', Statistical Papers, 33, pp. 335 - 359. 


\section{SURREY ENERGY ECONOMICS DISCUSSION PAPER SERIES (SEEDS) and SEEC OCCASIONAL PAPERS}

\section{SEEDS Number}

86 An Analysis of UK Energy Demand Using Multivariate Cointegration Lester C Hunt and Robert Witt ISBN 1852371803 December 1995

$85 \quad$ Freeing the Nuclear Industry

Colin Robinson ISBN 185237179X March 1996

84 The Efficiency of the National Electricity Board in Malaysia

- an Intercountry Comparison ISBN 185237165X January 1996

Jamaluddin bin Mohd Yunos and David Hawdon

83 Privatisation: Saving the British Coal Industry?

Colin Robinson ISBN 1852371633 November 1995

82 Electricity Privatisation in England and Wales: Progress and Problems Colin Robinson ISBN 1852371528 August 1995

SEEC OCCASIONAL PAPER

No.2 The S.E.E.C. United Kingdom Energy Demand Forecast (1995-2000) Update

Roger Fouquet, David Hawdon, Peter J G Pearson, Colin Robinson and Paul Stevens

ISBN $185237151 \mathrm{X}$

July 1995

81 The Nuclear Review

David Hawdon (Ed): Elroy Dimson, Robin Jeffrey, Martin O'Neill M.P., Colin Robinson and Mike Staunton ISBN $1852371501 \quad$ April 1995

80 Regulation as a Means of Introducing Competition

Colin Robinson ISBN $185237148 X \quad$ February 1995

79 Privatising Nuclear Power: evidence for the review of future prospects for nuclear power

Colin Robinson

ISBN $1852371455 \quad$ November 1994

78 Energy, Externalities and Environmental Quality: Will Development Cure the Ills it Creates?

Peter J.G. Pearson ISBN 1852371447 October 1994

77 The Demand for Car Fuel Efficiency: An Hedonic Price Approach $\begin{array}{lll}\text { Robert Witt } & \text { ISBN } 1852371439 & \text { October } 1994\end{array}$ 


\section{SURREY ENERGY ECONOMICS DISCUSSION PAPER SERIES (SEEDS) and SEEC OCCASIONAL PAPERS (contd)}

SEEDS Number

76 Economics and the Environment - The Shadow Price of

Greenhouse Gases and Aerosols

David Maddison

ISBN 1852371412

July 1994

$75 \quad$ End Use Elasticities

Joseph G Hirschberg

ISBN 1852371404

June 1994

74 A Model of Relative Price Elasticities from the Second Moments of Demand Joseph G Hirschberg

ISBN 1852371390

June 1994

Liberalisation of the Energy Market: A Favourable

Supply-side Shock for the UK Economy

Colin Robinson

ISBN 1852371382

June 1994

SEEC OCCASIONAL PAPER

No.1 The Future of UK Energy Demand - The S.E.E.C. United Kingdom Energy

Demand Forecast (1993-2000)

Roger Fouquet, David Hawdon, Peter J G Pearson, Colin Robinson

and Paul Stevens

ISBN 185237134X 16 December 1993

Recent Studies of the Demand for Energy in the UK

D Hawdon (Ed): Joyce Dargay, Roger Fouquet, Andrew Henley,

Keith Miller and John Peirson

ISBN $1852371331 \quad$ November 1993

71

An Econometric Study of the Demand for Gasoline in the Gulf Cooperation Council Countries ISBN 1852371315 October 1993

M Nagy Eltony \& Mohammad Almahmeed

70

International Bargaining and the EC Large Combustion Plant Directive

Roger Fouquet

ISBN $1852371129 \quad$ July 1993

69 Fuels for Electricity Supply after the UK Coal Review

Peter J G Pearson (Ed): Anthony Baker, Nigel Evans, PMS Jones and Colin Robinson

ISBN 1852371099

May 1993

68 Electricity in the Third World

Peter J G Pearson (Ed): Andrew Barnett, Gerald Foley, Francis McGowan and Peter J G Pearson

ISBN 1852371080

May 1993

Details of SEEDS 1-67, prices and annual Subscription Scheme on request 